\section{Ladies of inequality}

Janet Browne

Sexual Science: The Victorlan Construction of Womanhood. By Cynthia Eagle Russett. Harvard University Press: 1989. Pp. 245. \$25, £15.95.

DEsPITE the racy title, Sexual Science is a serious book about a serious subject. Cynthia Eagle Russett is professor of history at Yale University, and author of a number of studies on the relations between science and society in nineteenthcentury America. Previously, she has focused on the way that non-scientists absorbed the implications of darwinism and the idea of thermodynamic equilibrium.

In this new book, she turns to a more complicated intermingling of worlds and takes a long, hard look at nineteenthcentury science itself in order to chart the diverse and often inconsistent views that were expressed in both Britain and North America about the physical and social state of women. Many readers will perhaps be grateful that no modern axes are publicly ground, although the author is fully conversant with the latest work in womens' studies. But this does not mean that her story is a happy one: on the contrary, it fully justifies her claim that scientific work on sex differences during the Victorian period was neither unbiased nor value-free.

Philosophers, scientists, social theorists and the ordinary people in the nineteenthcentury streets were all united in their belief that women were significantly different from men. Eagle Russett des-

cribes how these simple beliefs The 'New Woman' of the 1880 s and 1890 s - "upbraided for overabout basic biology were developing her mind to the detriment of her role as a mother. turned into major scientific concepts. The first section of the book, primarily following the work of Stephen J. Gould on the mismeasurement of skulls, is concerned with the way obvious anatomical differences were interpreted. The anthropological system of measuring skulls was used by biologists to show that the size of the female brain case was smaller than that of males (despite considerable evidence to the contrary), a conclusion that was thought to confirm the mental inferiority of women. Similarly, the popular science of phrenology codified all sorts of differences in the mental faculties of men and women.

These structural observations were

supported by a wide range of physiological findings. Taking up one of the great nineteenth-century achievements in the study of physiology, biologists such as Patrick Geddes and J. Arthur Thomson defined men as 'katabolic' entities, metabolically active, and women as 'anabolic', 